\title{
Psykososiale tiltak etter en terrorhandling
}

\author{
Terrorhandlingene i Regjeringskvartalet og på Utøya vakte sterke følelser blant de som ble direkte rammet, \\ pårørende, venner, kolleger og befolkningen for øvrig. Det ble etablert flere sentre for overlevende og \\ pårørende både utenfor og på sykehus. Hva bør settes inn av psykososiale tiltak i en slik situasjon?
}

Villigheten til å stille opp og hjelpe var stor fra familie, venner, helsepersonell, frivillige organisasjoner og landets ledere. Dette aktualiserer spørsmålet om i hvilken grad psykiatrisk kriseintervensjon skal tilbys i den akutte fasen. Det har vært delte oppfatninger om dette i fagmiljøene. Det er dokumentert effekt av traumefokusert kognitiv terapi ved akutt stresslidelse (1) og posttraumatisk stresslidelse (2), men lite om tiltak i akuttfasen. Derfor bør arbeidet baseres på godt klinisk skjønn.

\section{Reaksjonene varierer}

Et grunnleggende prinsipp i medisinsk behandling er å diagnostisere somatiske, psykiske og sosiale helseproblemer og intervenere i forhold til disse. Noen er felles og må alltid forsøkes dekket, f.eks. å komme i sikkerhet, sikre næringsinntak og gi informasjon. For mye informasjon kan virke overveldende og traumatiserende. Når pasienter og pårørende har konkrete spørsmål, kan man regne med at de er forberedt på å få et ærlig svar. Unnvikelse eller falsk beroligelse virker mot sin hensikt. Svar om dødsfall må vente til det er offisielt stadfestet av lege eller politi, selv om en fagperson kanskje kan se at en person er død.

Når det gjelder andre reaksjoner, varierer symptombilde og behov. Mange ønsker å gi uttrykk for tanker og følelser, både for å bli hørt og forstått. Aktiv lytting er vanligvis strukturerende og hjelpsomt. Det er ikke grunn til å etterlyse spesielle reaksjoner. Noen har behov for å gråte og opplever en lettelse ved det, mens det ikke er naturlig for andre. Det samme gjelder behovet for å snakke om opplevelsene. Mange kan bearbeide sterke opplevelser på egen hånd. Andre kan raskt gjenoppta daglige aktiviteter, noe som vanligvis er gunstig. Den somatiske tilstanden er også viktig, og hvis pasienten er svært syk, må den psykologiske bearbeidingen vente.

\section{Kriseintervensjon}

Det er en del uenigheter om når man bør gi kriseintervensjon. Ledende fagpersoner fraråder en formalisert tidlig intervensjon overfor alle som har vært involvert i en traumatisk hendelse, og mener det bør foretas en screening før intervensjon (3). Det er imidlertid sannsynlig at psykologisk kompetente personer også kan bidra i den akutte fasen. Da bør fokus være på den aktuelle somatiske tilstanden, reaksjoner her og nå, slik at pasientene får fortalt om det de ønsker. Derimot bør man være tilbakeholdende med å ta opp temaer som kan vente.

De fleste reaksjoner er normale ved svære påkjenninger, noe som den rammede bør få bekreftet. Allikevel har den som er rammet, ofte behov for profesjonell hjelp. Det forekommer også reaksjoner som ikke bør normaliseres, slik som dissosiering (f.eks. ikke være i kontakt med seg selv eller andre), benekting (som er noe annet enn bagatellisering) eller psykotiske reaksjoner.

Ved store katastrofer kan et psykososialt kriseteam avlaste intensivavdelinger for samtaler som de normalt har tid til. De ansatte ved somatiske avdelinger kan føle seg usikre når det kommer et stort antall skadede pasienter med omfattende psykiske reaksjoner, og kan trenge veiledning. Dette var tilfelle bl.a. etter tsunamien i desember 2004, hvor sykepleierne fikk systematisk veiledning, noe som gjorde dem tryggere og pasientene tilfredse (4).

\section{Skyldfølelse er vanlig}

Pasienter og pårørende kjenner vanligvis sine behov. En behandler bør imidlertid spørre om det foreligger symptomer som søvnproblemer, angst eller depresjon, og må kunne skille mellom depresjon og sorg. Skyldfølelse er ikke uvanlig, kanskje for å ha overlevd eller for ikke å ha gjort nok. I så fall kan man spørre hvordan vedkommende kom til en slik konklusjon, oppfordre til å høre på andres vurderinger, understreke at vedkommende gjorde sitt beste og forklare hvorfor skyldfølelse er så vanlig.

Hovedproblemene varierer mye, og det gjør også tiden det tar for å løse disse. Den rammede kan ha problemer med rus eller økonomi som kan komplisere krisereaksjonene, og slike problemer bør ivaretas av adekvat instans.

I en katastrofesituasjon er viljen til å hjelpe stor på alle nivåer. Muligens iverksetter man for omfattende tiltak. Det er usikkert om det er indikasjon for at alle skal undersøkes av lege, både av hensyn til ressursbruk og ansvaret den enkelte har for egen helse. De fleste som trenger det, søker nok hjelp hvis tilbudet eksisterer. Med unntak av torturpregede traumer klarer de fleste seg uten helsehjelp. Selv om mange har akutte behandlingsbehov, er det mange som ikke har det. Mye kan falle på plass de første dagene, og mange har tilstrekkelig støtte fra familie og venner. Det er også noen som først får problemer etter flere måneder (5), noe som ikke betyr at sjansen for bearbeiding er redusert.

\section{Andre må ikke glemmes}

Hva med andre traumatiserte? Det er forståelig at det gis mye psykososial støtte etter terrorhandlingene 22. juli 2011, både i den akutte fasen og ved god oppfølging i den lokale og spesialiserte helsetjenesten. Allikevel må vi ikke glemme at det daglig er mennesker som traumatiseres alvorlig i forbindelse med trafikkulykker, blind vold, selvmordsatferd, hjertestans, meningitt eller annet hvor livet blir snudd på hodet. Mange får langvarige opphold på intensiv- og andre avdelinger. Ikke minst i akuttfasen har mange pårørende store belastninger. Noen pasienter får psykososial oppfølging på sykehus, men det skal mye til for at det blir vurdert at de trenger helsehjelp ved distriktspsykiatriske sentre etter utskrivning. Det er relativt sjelden at pårørende tilbys tilsvarende hjelp. Det gjenstår nok en del før de psykososiale krisetilbud blir like gode når katastrofer begrenses til den enkelte familie som når den får et større omfang.

\section{Øivind Ekeberg}

oivind.ekeberg@uus.no

Akuttmedisinsk avdeling

Oslo universitetssykehus Ullevål

Øivind Ekeberg (f. 1945) er overlege ved Akuttmedisinsk avdeling på Oslo universitetssykehus, Ullevål.

Ingen oppgitte interessekonflikter.

\section{Litteratur \\ 1. Roberts NP, Kitchiner JN, Kenardy J et al. Early psychological interventions to treat acute trau- matic stress symptoms. Cochrane Database Syst Rev. 2010; nr. 3 CD007944. \\ 2. Psykososiale tjenester ved katastrofer. Hvilke tiltak viser positiv effekt? Rapport IS-1238. Oslo: Sosial-og helsedirektoratet, 2005. www.helsedirektoratet.no/vp/multimedia/archive/ 00000/IS-1238 887a.doc (31.8.2011). \\ 3. Bisson JI, Tavakoly B, Witteveen AB et al. TENTS guidelines: development of post-disaster psycho- social care guidelines through a Delphi process. Br J Psychiatry 2010; 196: 69-74. \\ 4. Ekeberg $\emptyset$, Skogstad L, Myhrer SH. Tsunamien - ettervirkninger for overlevende og pårørende. Tidsskr Nor Legeforen 2008; 128: 1939-43. \\ 5. Tøien K, Myhren H, Schou IS et al. Psychological distress after severe trauma: a prospective 1-year follow-up study of a trauma intensive care unit population. J Trauma 2010; 69: 1552-9}

Mottatt 18.8. 2011 og godkjent 30.8. 2011.

Medisinsk redaktør Erlend Hem. 